\title{
Pengaruh Rasio Keuangan Terhadap Harga Saham Perusahaan Otomotif Periode 2013-2017
}

\author{
Efrizon \\ Pascasarjana Universitas Andalas \\ Jalan Universitas Andalas, Limau Manis, Pauh, Kota Padang, Indonesia, 25163 \\ Efrizon@bsm.co.id
}

\begin{abstract}
The study aims to determine: (1) the effect of current ratio on stock price, (2) the effect of ROE on stock price, (3) the effect of debt to equity ratio on stock price, (4) the effect of earning per share on stock price. The Current Ratio, ROE, $D E R$, EPS have a very important role to stock price. This study uses secondary data from annual reports and financial statements on automotive companies listed on Indonesian Stock Exchange period 2013-2017 by using purposive sampling method. There are 10 company samples or 50 observations that meet the criteria of the study sample. Analysis method in this research is panel data regression analysis. The results of this study indicate that the current ratio, return on equity, debt to equity ratio not significantly affect stock price. EPS can affect stock price significantly. However, the combination of current ratio, return on equity, debt to equity ratio and earning per share affect stock price simultaneously.
\end{abstract}

Keywords: Current Ratio, ROE, DER, EPS, Stock Price

\begin{abstract}
Abstrak
Tujuan penelitian ini adalah untuk menguji: (1) pengaruh current ratio terhadap harga saham, (2) pengaruh ROE terhadap harga saham, (3) pengaruh DER terhadap harga saham, (4) pengaruh EPS terhadap harga saham. Current ratio, ROE, DER, EPS memiliki peranan yang penting terhadap harga saham. Penelitian ini menggunakan data sekunder dari laporan keuangan tahunan perusahaan otomotif yang terdaftar di Bursa Efek Indonesia periode 20132017 dengan menggunakan metode purposive sampling. Terdapat 10 perusahaan yang menjadi sampel penelitian atau 50 observasi yang memenuhi kriteria sampel. Penelitian ini menggunakan metode analisis regresi data panel. Hasil penelitian menunjukkan bahwa current ratio, ROE, DER tidak mempunyai pengaruh yang signifikan terhadap harga paham. Sedangkan secara simultan, current ratio, ROE, DER dan EPS mempunyai pengaruh terhadap harga saham.
\end{abstract}

Kata Kunci: Current Ratio, ROE, DER, EPS, Harga saham

\section{PENDAHULUAN}

Laporan keuangan terdiri dari daftar-daftar (forms) yang disusun berdasarkan aturan-aturan tertentu dengan tujuan memberikan informasi keuangan yang berguna untuk pengambilan keputusan ekonomis (Syakur, 2015). Laporan keuangan menggambarkan kondisi perusahaan masa lalu, masa sekarang dan masa depan. Laporan keuangan juga dapat digunakan sebagai alat ukur kinerja perusahaan.

Kinerja perusahaan merupakan informasi yang sangat penting bagi investor. Kinerja perusahaan menjadi dasar pertimbangan investor untuk mengambil keputusan mengenai pembelian saham perusahaan tersebut. Dari pembelian saham maka calon investor dan investor mengharapkan akan mendapatkan keuntungan seperti memeroleh deviden, memeroleh capital gain dan juga memiliki suara bagi pemegang saham biasa. Oleh karena itu, calon investor dan investor tentunya akan memilih perusahaan yang memiliki kinerja yang bagus sebelum melakukan pembelian terhadap saham perusahaan tersebut. Saham perusahaan yang memiliki kinerja yang bagus akan menarik banyak investor untuk melakukan pembelian saham tersebut sehingga akan terjadi peningkatan permintaan terhadap saham perusahaan. Peningkatan permintaan saham mengakibatkan harga saham perusahaan juga akan meningkat. Namun sebaliknya, kinerja perusahaan yang turun dari waktu ke waktu menyebabkan penjualan saham menjadi turun.

Salah satu alat analisis untuk menilai harga saham perusahaan adalah dengan menggunakan analisis fundamental yaitu analisis rasio keuangan. Investor menggunakan rasio keuangan untuk menganalisis perusahaan dengan cara membandingkan rasio keuangan suatu perusahaan dengan 
perusahan sejenis sehingga memberikan kemudahan dan kecepatan dalam proses pengambilan keputusan. Pengaruh rasio keuangan terhadap harga saham telah diteliti oleh Sari \& Hakim (2017), yang bertujuan menemukan bukti pengaruh Current Ratio, Return On Equity (ROE), Debt to Equity Ratio (DER) dan Earning Per Share (EPS) terhadap Harga Saham perusahaan property dan real estate yang terdaftar di Bursa Efek Indonesia pada periode 2011-2015. Sari \& Hakim (2017) menggunakan metode analisis regresi linear berganda dengan bantuan Microsoft Excel 200 dan SPSS versi 20.0 dengan metode stepwise.

Sari \& Hakim (2017) menguji pengaruh current ratio terhadap harga saham perusahaan property dan real estate. Current ratio mengindikasikan kemampuan perusahaan untuk memenuhi utang-utang jangka pendek dengan menggunakan aset lancar. Perusahaan yang mampu membayar utang-utang jangka pendek dianggap perusahaan yang likuid. Semakin tinggi current ratio maka perusahaan semakin likuid sehingga meningkatkan permintaan terhadap saham perusahaan. Sari \& Hakim (2017) menemukan bukti bahwa current ratio tidak berpengaruh terhadap harga saham perusahaan property dan real estate. Hasil penelitian ini didukung oleh hasil penelitian yang dilakukan oleh Azmi, Andini \& Raharjo (2016); Muflihah (2017). Namun Rizanti \& Husaini (2017); Sondakh et al. (2014); Wijaya (2017) menemukan bukti bahwa current ratio mempunyai pengaruh signifikan terhadap harga saham.

Sari \& Hakim (2017) menguji pengaruh $R O E$ terhadap harga saham perusahaan property dan real estate. ROE mengukur kemampuan perusahaan untuk menghasilkan laba dari investasi pemegang saham di perusahan tersebut. Rasio ini penting bagi investor dan calon investor karena dapat mengetahui seberapa efisien perusahaan menggunakan uang yang diinvestasikan oleh calon investor dan investor untuk menghasilkan laba bersih. Sari \& Hakim (2017) menemukan bukti bahwa $R O E$ berpengaruh negatif signifikan terhadap harga saham perusahaan property dan real estate. Hasil penelitian ini didukung oleh hasil penelitian yang dilakukan oleh Rizanti \& Husaini (2017); Tumandung, Murni, \& Baramuli (2017); Wijaya (2017). Namun, Utami \& Darmawan (2018) menemukan bukti bahwa $R O E$ tidak mempunyai pengaruh signifikan terhadap harga saham.

Sari \& Hakim (2017) menguji pengaruh DER terhadap harga saham perusahaan property dan real estate. DER menunjukkan proporsi relatif antara modal dan utang yang digunakan untuk membiayai aset perusahan. Rasio keuangan ini penting bagi calon investor dan investor karena dapat mengetahui apakah perusahaan dibiayai dari utang atau dari modal sendiri. Calon investor dan investor akan lebih menyukai perusahaan yang memiliki $D E R$ yang rendah. Sari \& Hakim (2017) menemukan bukti bahwa DER tidak berpengaruh terhadap harga saham perusahaan property dan real estate. Hasil penelitian ini didukung oleh hasil penelitian yang dilakukan oleh Muflihah, (2017); Rizanti dan Husaini (2017); Utami dan Darmawan (2018). Namun, Hutapea et al. (2017); Sondakh et al, (2014) menemukan bukti bahwa DER berpengaruh signifikan terhadap harga saham.

Sari \& Hakim (2017) menguji pengaruh EPS terhadap harga saham perusahaan property dan real estate. EPS merupakan bagian dari laba perusahaan yang dialokasikan ke setiap saham yang beredar. Rasio keuangan ini penting bagi calon investor dan investor karena dapat memberikan gambaran profitabilitas perusahaan. Calon investor dan investor akan menginvestasikan dananya pada perusahaan yang EPS-nya terus mengalami peningkatan. Sari \& Hakim (2017) menemukan bukti bahwa EPS berpengaruh positif signifikan terhadap harga saham perusahaan property dan real estate. Hasil penelitian ini didukung oleh hasil penelitian yang dilakukan oleh Wijaya (2017); Rahmawati, (2018); Utami dan Darmawan (2018). Namun, hasil penelitian mereka tidak sesuai dengan hasil penelitian dari Tarigan (2018).

Penelitian ini merupakan replikasi dari penelitian Sari \& Hakim (2017). Peneliti melakukan replikasi penelitian Sari \& Hakim (2017) karena masih terdapat gap hasil penelitian. Peneliti berharap hasil penelitian ini nantinya akan dapat memberikan kontribusi teoritis terhadap pengaruh current ratio, ROE, DER dan EPS terhadap harga saham. Perbedaan penelitian ini dengan penelitian yang dilakukan oleh Sari \& Hakim (2017) adalah, pertama penelitian ini menggunakan perusahaan otomotif yang terdaftar di Bursa Efek Indonesia. Alasan pengambilan perusahaan otomotif sebagai sampel penelitian adalah perkembangan perusahaan otomotif Indonesia sangat pesat sehingga menarik perhatian investor untuk menanamkan modal pada sektor otomotif. 
Dunia otomotif berkembang cukup pesat di Indonesia. Pasar otomotif terus tumbuh secara signifikan beberapa tahun terakhir seperti yang terlihat pada Gambar 1. Pada tahun 2008, jumlah kendaraan bermotor sebanyak 61.685.063 unit dan mengalami peningkatan sebesar 138.556.669 unit (125\%) dalam kurun waktu 10 tahun. Sepeda motor merupakan kendaraan bermotor yang paling banyak, disusul oleh mobil penumpang, mobil barang dan yang terakhir mobil bis.

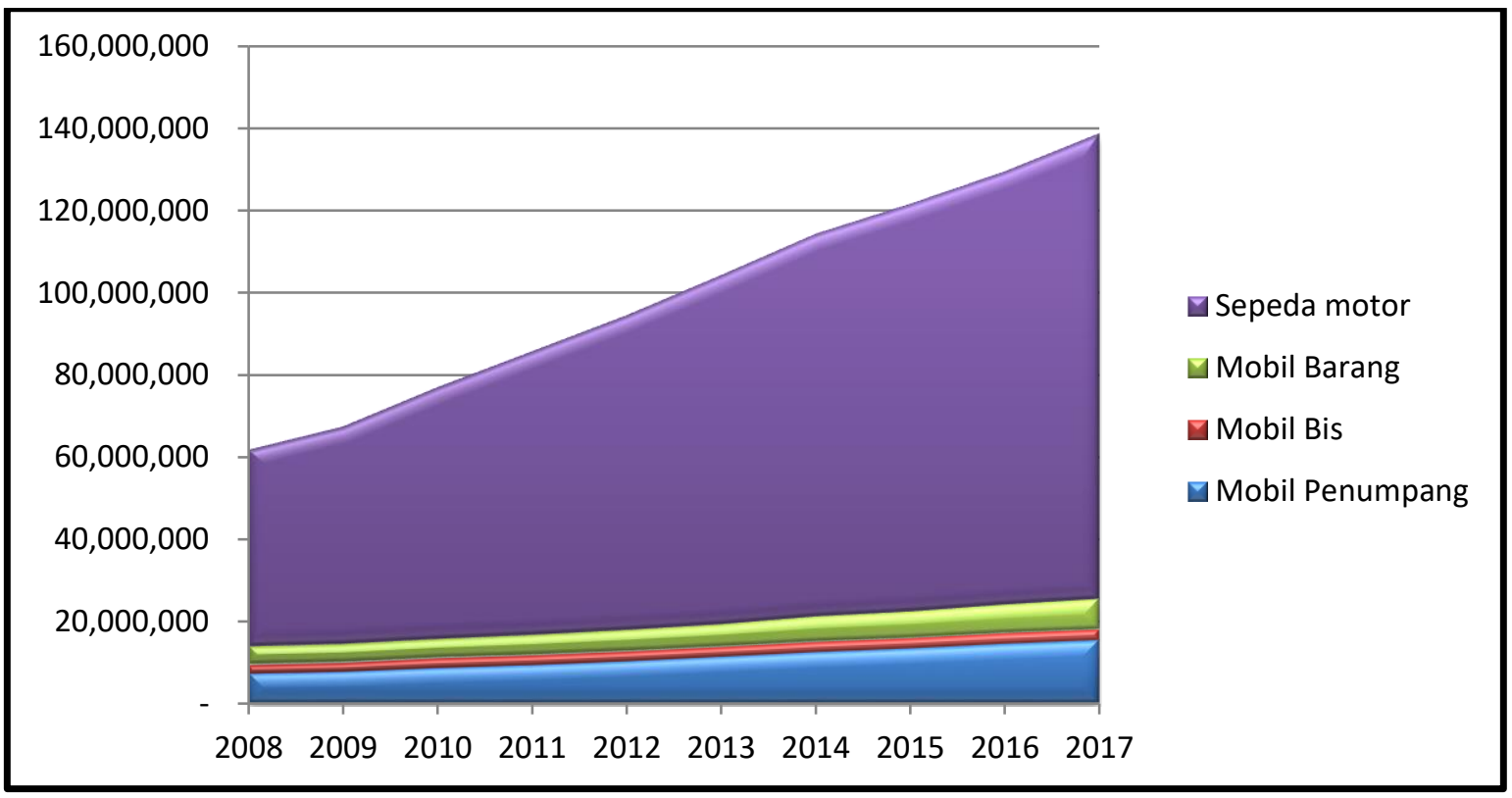

Gambar 1. Perkembangan Jumlah Kendaraan Bermotor di Indonesia (Sumber: badan pusat statistik)

Syari'udin (2017) menyebutkan bahwa pertumbuhan pasar otomotif di Indonesia didukung oleh kondisi ekonomi yang relatif stabil. Syari'udin (2017) juga memaparkan hasil penelitian Vijay Rao (2016), Automotive and Transportation Practice Frost \& Sullivan yang menyatakan bahwa perkembangan otomotif di Indonesia berada di peringkat kedua terbesar di ASEAN setelah Thailand. Bahkan pada tahun 2019, Indonesia akan menjadi pasar otomotif terbesar di ASEAN dengan total kendaraan mencapai 2,3 juta unit. Hal ini tentunya akan menarik banyak investor untuk menanamkan modalnya pada sektor otomotif di Indonesia.

Perbedaan kedua penelitian ini dengan penelitian Sari \& Hakim (2017) adalah penelitian ini menggunakan metode analisis regresi data panel dengan bantuan Eviews 9. Penggunaan analisis regresi data panel lebih tepat digunakan untuk menguji pengaruh variabel independen terhadap variabel dependen pada jenis data panel dibandingkan analisis regresi linear berganda.

Berlandaskan latar belakang permasalahan di atas, maka rumusan masalah dalam penelitian ini adalah sebagai berikut:

1. Apakah current ratio berpengaruh terhadap harga saham perusahaan otomotif yang listing di Bursa Efek Indonesia?

2. Apakah $R O E$ berpengaruh terhadap harga saham perusahaan otomotif yang listing di Bursa Efek Indonesia?

3. Apakah $D E R$ berpengaruh terhadap harga saham perusahaan otomotif yang listing di Bursa Efek Indonesia?

4. Apakah EPS berpengaruh terhadap harga saham perusahaan otomotif yang listing di Bursa Efek Indonesia?

\section{Landasan Teori}

\section{Teori Signaling}

Manajer perusahaan mempunyai informasi yang lebih bagus mengenai kondisi perusahaan masa sekarang dan masa yang akan datang dibandingkan dengan pihak luar, seperti investor, kreditor dan pemerintah. Kondisi ini disebut dengan asimetri informasi. Keberadaan asimetri informasi 
sangat menyulitkan investor dalam membedakan antara perusahaan yang bagus dengan perusahaan yang jelek secara obyektif. Investor pun menjadi ragu dalam menilai perusahaan-perusahaan yang ada sehingga pada akhirnya menganggap bahwa semua perusahaan adalah jelek atau tidak baik (pooling equilibrium). Jusny (2014) menyatakan bahwa teori sinyal adalah teori yang menjelaskan tentang bagaimana manajer perusahaan memberikan sinyal kepada pihak luar perusahaan. Sinyal dapat berwujud dalam berbagai bentuk, baik yang dapat diamati secara langsung maupun harus dilakukan analisis yang mendalam terlebih dahulu sehingga pihak luar perusahaan akan melakukan perubahan penilaian atas perusahaan (Gumanti, 2009).

\section{Rasio Keuangan}

Tujuan utama laporan keuangan adalah untuk memberikan informasi tentang kinerja perusahaan. Metode yang paling tua dan paling praktis untuk menilai kinerja perusahaan adalah rasio keuangan (Arkan, 2016). Rasio keuangan telah digunakan pada pertengahan abad 19 oleh akuntan dan analis keuangan. Rasio keuangan digunakan oleh pihak internal dan eksternal perusahaan untuk membantu mereka mengambil keputusan ekonomi, termasuk investasi dan penilaian kinerja.

Arkan (2016) membagi rasio keuangan menjadi lima kategori yaitu: (1) leverage financial ratios, (2) liquidity financial ratios, (3) financial operation ratios, (4) profitability financial ratios, (5) valuation ratios. Leverage Financial Ratio merupakan rasio yang menggambarkan stuktur modal perusahaan. Liquidity Financial Ratio merupakan rasio yang menggambarkan kemampuan perusahaan untuk membayar kewajiban jangka pendek dengan menggunakan aset lancar. Financial Operation Ratio atau biasa juga disebut asset management ratio, mengukur efisiensi perusahaan menggunakan aset dalam menghasilkan penjualan atau pendapatan. Profitability financial ratio atau biasa juga disebut performance ratio, menilai kemampuan perusahaan menghasilkan laba. Valuation ratio menggambarkan ukuran kemampuan manajemen menciptakan nilai pasar usahanya di atas biaya investasinya. Tabulasi rasio keuangan ini dapat dilihat pada Tabel 1.

Tabel 1. Rasio Keuangan

\begin{tabular}{|c|c|c|c|}
\hline No & Kategori & Rumus & Rasio \\
\hline \multirow[t]{2}{*}{1} & Liquidity & Current Assets: Current Liabilities & Current Ratio \\
\hline & & $\begin{array}{l}\text { Current Assets - Inventory - Prepaid Items: Current } \\
\text { Liabilities }\end{array}$ & Quick Ratio \\
\hline \multirow[t]{3}{*}{2} & $\begin{array}{l}\text { Leverage } \\
\text { Financial Ratios }\end{array}$ & Debt: Total Assets & Debt Ratio \\
\hline & & Total Liabilities: Total Stockholders' Equity & Debt to Equity \\
\hline & & Short Term Liabilities: Total Stockholders' Equity & $\begin{array}{l}\text { Short-term Debt to } \\
\text { Equity }\end{array}$ \\
\hline \multirow[t]{2}{*}{3} & Operation Ratios & Sales: Average Fixed Assets & $\begin{array}{l}\text { Fixed Asset Turnover } \\
\text { Ratio }\end{array}$ \\
\hline & & Sales: Average Total Assets & $\begin{array}{l}\text { Total Asset Turnover } \\
\text { Ratio }\end{array}$ \\
\hline \multirow[t]{4}{*}{4} & $\begin{array}{l}\text { Profitability } \\
\text { Ratios }\end{array}$ & Net Income: Average Total Assets & $\begin{array}{l}\text { Return on Total } \\
\text { Assets Ratio }\end{array}$ \\
\hline & & $\begin{array}{l}\text { Net Income Available to Common Stockholders: } \\
\text { Average Common Stockholder's Equity }\end{array}$ & $\begin{array}{l}\text { Return on Equity } \\
\text { Ratio }\end{array}$ \\
\hline & & (Sales - COGS): Sales & Gross Margin Ratio \\
\hline & & Net Profit After Tax: Net Sales & Net Profit Ratio \\
\hline 5 & Valuation Ratios & $\begin{array}{l}\text { (Stock price } x \text { Number of Shares outstanding): Total } \\
\text { Stockholders' Equity }\end{array}$ & EPS Market to Book \\
\hline
\end{tabular}


Sumber: Arkan (2016)

\section{METODE}

\section{Jenis Penelitian}

Peneliti menggunakan jenis penelitian kuantitatif bersifat kausal. Penelitian kuantitatif adalah penelitian yang data penelitiannya berupa angka sedangkan penelitian kausal merupakan penelitian yang menguji apakah perubahan satu variabel mengakibatkan terjadinya perubahan variabel lainnya (Sekaran \& Bougie, 2016).

\section{Variabel Penelitian dan Definisi Operasional Variabel}

Dalam penelitian ini variabel dependen adalah harga saham. Sementara, variabel independen yang digunakan adalah current ratio, ROE, DER dan EPS. Variabel dalam penelitian ini dituliskan pada Tabel 2.

Tabel 2. Variabel, Jenis dan Indikator

\begin{tabular}{lll}
\hline Variabel & Jenis & Indikator \\
\hline Harga Saham & Dependen & $\begin{array}{l}\text { Harga pasar yang tercatat pada waktu penutupan (closing price }) \\
\text { di Bursa Efek Indonesia pada periode akhir tahun }\end{array}$ \\
\hline Current Ratio & Independen & $\begin{array}{l}\text { Kemampuan perusahaan memenuhi kewajiban jangka } \\
\text { pendeknya } \\
\text { Current Ratio }=\frac{\text { Aktiva Lancar }}{\text { Utang Lancar }}\end{array}$ \\
\hline ROE & Independen & Jumlah laba yang menjadi hak pemilik modal sendiri \\
& ROE $=\frac{\text { Laba bersih }}{\text { Modal sendiri }}$ \\
\hline DER & Independen & Kemampuan modal pemilik menutupi utang pada pihak luar \\
& DER $=\frac{\text { Total Utang }}{\text { Total Modal }}$ \\
\hline EPS & Independen & $\begin{array}{l}\text { Keuntungan yang diperoleh pemegang saham per lembar } \\
\text { saham }\end{array}$ \\
& EPS $=\frac{\text { EAT }}{\text { Jumlah Lembar Saham }}$ \\
\hline
\end{tabular}

Sumber: Utami dan Darmawan (2018)

\section{Populasi dan Sampel}

Penelitian ini menggunakan seluruh perusahaan otomotif yang terdaftar di Bursa Efek Indonesia tahun 2013-2017 sebagai populasi penelitian. Peneliti menggunakan metode purposive sampling dalam menentukan sampel penelitian. Kriteria penentuan sampel yang peneliti gunakan adalah sebagai berikut: (1) telah go public di BEI periode 2013-2017, (2) perusahaan menerbitkan laporan keuangan periode 2013-2017, (3) perusahaan memiliki data lengkap yang berkaitan dengan penelitian ini. Berdasarkan kriteria tersebut, perusahaan otomotif yang menjadi sampel penelitian ini berjumlah 10 perusahaan.

\section{Metode Analisis}

Penelitian ini menggunakan model regresi data panel yang didasarkan pada data panel untuk membuktikan secara statistk pengaruh satu variabel bebas dengan satu atau beberapa variabel terikat. Data panel merupakan penggabungan data time series dan data cross section. Data time series dalam penelitian ini adalah data tahunan periode 2013-2017 sedangkan data cross section yang digunakan adalah 10 perusahaan otomotif yang merupakan objek penelitian. Penelitian ini melakukan pengamatan sebanyak 50 observasi yaitu hasil perkalian jumlah tahun dengan jumlah perusahaan. Model penelitian yang digunakan adalah sebagai berikut: 


$$
Y=\alpha+\beta_{1} X_{1 i t}+\beta_{2} X_{2 i t}+\beta_{3} X_{3 i t}+\beta_{4} X_{4 i t}+e
$$

Keterangan:

$\begin{array}{ll}\alpha & \text { : Konstanta } \\ \beta_{1-} \beta_{4} & \text { : Koefisien masing-masing variabel } \\ \mathrm{X} 1 & \text { : Current Ratio } \\ \mathrm{X} 2 & \text { : ROE } \\ \mathrm{X} 3 & \text { : DER } \\ \mathrm{X} 4 & \text { : EPS } \\ \mathrm{e} & \text { : Error }\end{array}$

\section{Pengujian Hipotesis}

Setelah pengolahan data selanjutnya peneliti melakukan pengujian terhadap hasil output yaitu, uji t, uji $\mathrm{F}$ dan Koefisien Determinasi $\left(\mathrm{R}^{2}\right)$.

1. Uji t dilakukan untuk mengetahui signifikansi variabel independen terhadap variabel dependen secara parsial dengan asumsi variabel independen lain dianggap konstan. Jika nilai $t_{\text {hitung }}<\mathrm{t}_{\text {tabel }}$ atau sig $\leq \alpha=0,05, \mathrm{H}_{\mathrm{o}}$ ditolak dan $\mathrm{H}_{\mathrm{a}}$ diterima. Dengan demikian, variabel independen mempengaruhi variabel dependen secara parsial.

2. Uji $\mathrm{F}$ dilakukan untuk mengetahui signifikansi variabel independen terhadap variabel dependen secara bersamaan. Jika nilai $F_{\text {hitung }} \geq F_{\text {tabel }}$ atau sig $\leq \alpha=0,05, H_{0}$ ditolak dan $\mathrm{H}_{\mathrm{a}}$. Dengan demikian, variabel dependen mempengaruhi variabel independent secara bersama-sama.

3. Koefisien Determinasi $\left(\mathrm{R}^{2}\right)$ menggambarkan kemampuan model dalam menjelaskan variasi variabel dependen. Semakin besar $\mathrm{R}^{2}$ maka semakin baik kemampuan semua variabel independen menjelaskan variabel dependen.

\section{HASIL DAN PEMBAHASAN \\ Deskripsi Objek Penelitian}

Penelitian ini menggunakan populasi perusahaan yang terdaftar di Bursa Efek Indonesia tahun 2013-2017. Sampel penelitian adalah perusahaan otomotif yang terdaftar di Bursa Efek Indonesia. Perincian perolehan sampel penelitian dapat dilihat pada Tabel 3 berikut.

Tabel 3. Sampel Penelitian Periode 2013-2017

\begin{tabular}{|c|c|}
\hline Kriteria Sampel & Jumlah \\
\hline Perusahaan otomotif yang terdaftar di BEI tahun 2013-2017 & 13 \\
\hline Perusahaan yang tidak melaporkan laporan keuangan selama tahun 2013-2017 & 3 \\
\hline Jumlah sampel penelitian & 10 \\
\hline
\end{tabular}

\section{Statistik Deskriptif}

Statistik deskriptif mempermudah dalam melihat gambaran variabel yang diteliti. Setelah melalui proses pengolahan dengan menggunakan program Eviews, variabel tersebut secara statistik seperti yang tergambar pada Tabel 4 berikut.

Tabel 4. Statistik Deskriptif

\begin{tabular}{lccccc}
\hline & $\mathrm{N}$ & Minimum & Maximum & Mean & Std Deviation \\
\hline Harga Saham & 50 & $1.250,00$ & $8.300,00$ & $2.393,54$ & $2.464,12$ \\
\hline Current Ratio & 50 & 83,28 & 512,54 & 170,25 & 86,29 \\
\hline ROE & 50 & $-7,78$ & 36,75 & 7,84 & 10,36 \\
\hline DER & 50 & 0,14 & 2,82 & 1,05 & 0,75 \\
\hline EPS & 50 & $-104,66$ & 672,11 & 143,96 & 183,55 \\
\hline
\end{tabular}

Berdasarkan hasil uji deskriptif pada Tabel 4, current ratio memiliki nilai rata-rata sebesar 170,25 yang berarti bahwa rata-rata perusahaan otomotif tidak mengalami masalah likuiditas karena 
memiliki rata-rata current ratio di atas 100 . Nilai maksimum untuk current ratio sebesar 512,54 yang berarti bahwa nilai paling tinggi untuk hutang lancar perusahaan jika dibandingkan dengan aset lancar terjadi tahun 2017 pada perusahaan Indospring. Yang paling rendah sebesar 83,28 tahun 2017 pada perusahaan Indomobil Sukses.

$R O E$ memiliki nilai mean sebesar 7,84 yang berarti bahwa rata-rata kemampuan perusahaan dalam memanfaatkan investasi pemegang saham untuk menghasilkan profitabilitas perusahaan adalah 7,84. Nilai paling tinggi yaitu 36,75 tahun 2014 pada perusahaan Selamat Sempurna dan yang paling rendah yaitu -7.7 8 tahun 2015 pada perusahaan Multistrada Arah Sarana.

DER memiliki nilai rata-rata sebesar 1,05 yang berarti bahwa rata-rata hutang perusahaan jika dibandingkan dengan ekuitas memiliki risiko sebesar 1,05 terhadap likuiditas perusahaan. Nilai maksimum untuk $D E R$ sebesar 2,82 yang berarti bahwa nilai paling tinggi untuk hutang perusahaan jika dibandingkan dengan ekuitas terjadi tahun 2016 pada perusahaan Indomobil Sukses. Yang paling rendah sebesar 0,14 tahun 2017 pada perusahaan Indospring.

EPS memiliki nilai mean sebesar 143,96 yang berarti bahwa pendapatan yang diperoleh per lembar saham adalah 143,96. Nilai paling tinggi yaitu 672,11 tahun 2017 pada perusahaan Indokordsa dan yang paling rendah yaitu -104,66 tahun 2016 pada perusahaan Indomobil Sukses.

\section{Estimasi Model Regresi Data Panel}

Estimasi model regresi data panel terbaik dipilih dengan melakukan uji chow, uji hausman, dan uji lagrange multiplier. Penelitian ini mengabaikan common effect, sehingga hanya melakukan uji hausman untuk memilih apakah Fixed Effect Model (FEM) atau Random Effect Model (REM) yang lebih tepat sebagaimana terlihat pada Tabel 5 .

Tabel 5. Hasil Uji Hausman

Correlated Random Effects - Hausman Test

Equation: Untitled

Test cross-section random effects

\begin{tabular}{lccc}
\hline \hline Test Summary & $\begin{array}{l}\text { Chi-Sq. } \\
\text { Statistic }\end{array}$ & Chi-Sq. d.f. & Prob. \\
\hline \hline Cross-section random & 6.733365 & 4 & 0.1507 \\
\hline \hline
\end{tabular}

Hasil uji hausman menunjukkan nilai probabilitas chi squares sebesar 0,1507. Oleh karena nilai probabilitas chi squares lebih besar dari taraf signifikansi $(0,15>0,05), \mathrm{H}_{0}$ diterima atau REM lebih tepat dibandingkan FEM.

\section{Estimasi Regresi Data Panel Random Effect Model (REM)}

Berdasarkan hasil uji Hausman, model terbaik untuk penelitian ini yaitu REM. Dengan demikian, regresi data panel dilakukan sesuai dengan model yang terpilih. Hasil estimasi dapat dilihat pada Tabel 6 berikut.

Tabel 6. Estimasi Regresi Data Panel Random Effect Model

Dependent Variable: HARGA_SAHAM

Method: Panel EGLS (Cross-section random effects)

Date: 02/20/19 Time: 16:12

Sample: 20132017

Periods included: 5

Cross-sections included: 10

Total panel (balanced) observations: 50

Swamy and Arora estimator of component variances 


\begin{tabular}{crrrr}
\hline Variable & Coefficient & Std. Error & t-Statistic & Prob. \\
\hline C & 1184.102 & 813.4586 & 1.455638 & 0.1524 \\
\hline CURRENT_RATIO & -2.563440 & 2.777131 & -0.923053 & 0.3609 \\
\hline ROE & -31.33076 & 31.31781 & -1.000413 & 0.3225 \\
\hline DER & 197.0233 & 389.5286 & 0.505799 & 0.6155 \\
\hline EPS & 11.70401 & 1.558161 & 7.511426 & 0.0000 \\
\hline
\end{tabular}

Berdasarkan hasil analisis regresi panel, nilai probabilitas untuk:

1. Variabel current ratio, ROE dan DER masing-masing sebesar 0,3609, 0,3225 dan 0, 6155 lebih besar dari tingkat signifikan sebesar 0,05 atau 5\%. Yang artinya variabel current ratio, ROE dan $D E R$ tidak signifikan sehingga tidak mempengaruhi harga saham pada perusahaan otomotif di BEI pada periode 2013-2017.

2. Variabel EPS menghasilkan nilai probabilitas masing-masing sebesar 0,0000 lebih kecil dari tingkat signifikan sebesar 0,05 atau 5\%. Yang artinya variable EPS berpengaruh signifikan terhadap harga saham pada perusahaan otomotif di BEI pada periode 2013-2017.

Dari hasil pengolahan data panel dengan menggunakan REM, dapat dibentuk model persamaan penelitian, seperti berikut ini:

$Y_{i t}=\beta_{0}+\beta_{1} C R_{i t}+\beta_{2} R O E_{i t}+\beta_{3} D E R_{i t}+\beta_{4} E P S_{i t}$

Harga Saham $_{i t}=1.184,10-2,56 C R_{i t}-31,33 R O E_{i t}+197,02 D E R_{i t}+11,70 E P S_{i t}$

\section{Uji Parsial (Uji t)}

Pengujian ini dilakukan dengan membandingkan nilai $p$ value. Jika $p$ value $>0,05$, maka $\mathrm{H}_{0}$ diterima dan Ha ditolak. Artinya, variabel independen yang diuji tidak berpengaruh secara signifikan terhadap variabel dependen. Sementara jika $p$ value $<0,05, \mathrm{H}_{0}$ ditolak dan Ha diterima. Artinya, variabel independen yang diuji berpengaruh secara signifikan terhadap variabel dependen.

Berdasarkan Tabel 6 maka dapat disimpulkan sebagai berikut:

1. Variabel current ratio, ROE dan DER memiliki $p$ value $>0,05$. Dengan demikian, Ho diterima dan Ha ditolak. Artinya, current ratio, ROE dan DER tidak berpengaruh signifikan terhadap harga saham.

2. Variabel EPS memiliki $p$ value $<0,05$. Dengan demikian, Ho ditolak dan Ha diterima. Artinya, EPS berpengaruh signifikan terhadap harga saham.

\section{Uji Simultan (Uji F)}

Jika nilai probabilitas $>0,05$, maka Ho diterima dan Ha ditolak. Artinya, variabel independen dalam persamaan tidak berpengaruh terhadap variasi dari variabel dependen secara simultan dan sebaliknya. Hasil estimasi regresi data panel dengan model REM yang menjabarkan nilai F-statistik dan Prob (F-statistic) dapat dilihat pada Tabel 7 berikut.

Tabel 7. Hasil Uji F

\begin{tabular}{ll}
\hline R-squared & 0.629515 \\
\hline Adjusted R-squared & 0.596583 \\
\hline S.E. of regression & 961.2919 \\
\hline F-statistic & 19.11557 \\
\hline Prob(F-statistic) & 0.000000 \\
\hline
\end{tabular}

Berdasarkan Tabel 7, dapat disimpulkan bahwa nilai probabilitas (F-statistic) $0,0000<0,05$ berarti Ho ditolak dan Ha diterima. Dengan demikian, seluruh variabel independen secara bersamasama berpengaruh signifikan terhadap variabel dependen. current ratio, ROE, DER dan EPS secara bersama-sama berpengaruh signifikan terhadap harga saham pada perusahaan otomotif di Indonesia yang terdaftar di BEI pada periode 2013-2017. 


\section{Koefisien Determinasi $\left(\mathbf{R}^{\mathbf{2}}\right)$}

Apabila $\mathrm{R}^{2}$ mendekati 1 (satu) berarti variabel-variabel independen memberikan hampir semua informasi yang dibutuhkan untuk memprediksi variasi variabel dependen. Berdasarkan Tabel 7 , dapat disimpulkan bahwa $R$ squared sebesar 0,62 atau $62 \%$. Hal ini berarti bahwa kemampuan variabel independen (Current Ratio, ROE, DER dan EPS) dalam menjelaskan variabel dependen (Harga Saham) sebesar 62\% sisanya sebesar 38\% dijelaskan oleh variabel lain di luar model.

\section{Pengaruh Current Ratio Terhadap Harga Saham}

Hasil pengujian hipotesis menyimpulkan bahwa current ratio berpengaruh negatif namun tidak berpengaruh signifikan terhadap harga saham pada perusahaan otomotif di BEI pada periode 2013-2017. Hasil penelitian ini menjelaskan bahwa tinggi atau rendah nilai current ratio tidak menujukkan pengaruh naik atau turun harga saham. Hasil penelitian ini sesuai dengan penelitian Sari \& Hakim (2017); Azmi, Andini dan Raharjo (2016); Muflihah (2017); Sari dan Hakim (2017) bahwa current ratio tidak berpengaruh signifikan terhadap harga saham.

\section{Pengaruh ROE Terhadap Harga Saham}

Hasil penelitian pada variabel $R O E$ terhadap harga saham perusahaan otomotif di BEI pada periode 2013-2017 yaitu berdasarkan hasil pengujian ROE menunjukkan tingkat nilai signifikansi sebesar 0,3225 lebih besar dari 0,05 $(0,3225>0,05)$. Artinya, $R O E$ tidak bepengaruh terhadap harga saham perusahaan otomotif di BEI pada periode 2013-2017. Hasil penelitian ini menjelaskan bahwa tinggi atau rendah nilai DER tidak menujukkan pengaruh naik atau turun harga saham perusahaan otomotif di BEI pada periode 2013-2017. Hasil penelitian ini sesuai dengan penelitian Utami \& Darmawan (2018) bahwa $R O E$ tidak berpengaruh signifikan terhadap harga saham perusahaan otomotif di BEI pada periode 2013-2017.

\section{Pengaruh DER Terhadap Harga Saham}

Hasil penelitian pada variabel $D E R$ terhadap harga saham perusahaan otomotif di BEI pada periode 2013-2017 yaitu berdasarkan hasil pengujian $D E R$ menunjukkan tingkat nilai signifikansi sebesar 0,6155 lebih besar dari 0,05 $(0,6155>0,05)$. Artinya, $D E R$ tidak bepengaruh terhadap harga saham perusahaan otomotif di BEI pada periode 2013-2017. Hasil penelitian ini menjelaskan bahwa tinggi atau rendah nilai DER tidak menujukkan pengaruh naik atau turun harga saham perusahaan otomotif di BEI pada periode 2013-2017. Hasil penelitian ini sesuai dengan penelitian Sari \& Hakim (2017); Muflihah (2017); Rizanti \& Husaini (2017); Utami \& Darmawan (2018) bahwa DER tidak berpengaruh signifikan terhadap harga saham perusahaan otomotif di BEI pada periode 2013-2017.

\section{Pengaruh EPS Terhadap Harga Saham}

Hasil penelitian pada variabel EPS terhadap harga saham perusahaan otomotif di BEI pada periode 2013-2017 yaitu berdasarkan hasil pengujian EPS menunjukkan tingkat nilai signifikansi sebesar 0,0000 lebih kecil dari 0,05 $(0,0000<0,05)$. Artinya, EPS bepengaruh terhadap harga saham perusahaan otomotif di BEI pada periode 2013-2017. Hasil penelitian ini menjelaskan bahwa tinggi atau rendah nilai $E P S$ menujukkan pengaruh naik atau turun harga saham perusahaan otomotif di BEI pada periode 2013-2017. Hasil penelitian ini sesuai dengan penelitian Rahmawati (2018); Sari \& Hakim (2017); Utami \& Darmawan (2018); Wijaya (2017) bahwa EPS berpengaruh signifikan terhadap harga saham perusahaan otomotif di BEI pada periode 2013-2017.

\section{SIMPULAN}

Hipotesis pertama ditolak, berdasarkan hasil penelitian yang menunjukkan bahwa Current Ratio berpengaruh negatif dan tidak signifikan terhadap Harga Saham. Dengan demikian, dapat disimpulkan bahwa semakin tinggi Current Ratio maka akan semakin rendah Harga Saham. Namun, pada perusahan otomotif tidak saling mempengaruhi antara Current Ratio dan Harga Saham. Hipotesis kedua ditolak, berdasarkan hasil penelitian yang menunjukkan bahwa ROE berpengaruh negatif dan tidak signifikan terhadap Harga Saham. Dengan demikian, dapat disimpulkan bahwa semakin tinggi $R O E$ maka akan semakin rendah Harga Saham. Namun, pada perusahan otomotif 
tidak saling mempengaruhi antara $R O E$ dan Harga Saham. Hipotesis ketiga ditolak, berdasarkan hasil penelitian yang menunjukkan $D E R$ berpengaruh positif dan tidak signifikan terhadap Harga Saham. Dengan demikian, dapat disimpulkan bahwa semakin tinggi $D E R$ maka akan semakin tinggi Harga Saham. Namun, pada perusahan otomotif tidak saling mempengaruhi antara DER dan Harga Saham. Hipotesis keempat diterima, berdasarkan hasil penelitian yang menunjukkan EPS berpengaruh positif dan signifikan terhadap Harga Saham. Dengan demikian, dapat disimpulkan bahwa semakin tinggi EPS maka akan semakin tinggi Harga Saham.

Berdasarkan hasil penelitian dan kesimpulan diatas, peneliti selanjutnya disarankan untuk: (1) menambah variabel independen yang diduga mempunyai pengaruh terhadap harga saham dari faktor makro perusahaan seperti tingkat suku bunga, inflasi, pertumbuhan ekonomi. (2) Memperluas jumlah populasi penelitian. (3) Memperpanjang periode penelitian supaya hasil penelitian dapat digeneralisasi.

Penelitian ini memiliki beberapa keterbatasan antara lain: (1) Periode penelitian yang cukup pendek yaitu hanya 5 tahun (2013-2017) sehingga sampel belum bisa mewakili keseluruhan kondisi perusahaan. (2) Penelitian ini hanya menggunakan perusahaan otomotif yang listing di BEI, sehingga hasil penelitian tidak mencerminkan secara keseluruhan reaksi pasar modal. (3). Penelitian ini hanya menggunakan rasio keuangan perusahaan yang diwakili oleh current ratio, ROE, DER, dan EPS. (4) Penelitian ini tidak menguji faktor makro seperti tingkat suku bunga, inflasi dan lain-lain.

\section{DAFTAR RUJUKAN}

Arkan, T. (2016). The Importance of Financial Ratios in Predicting Stock Price Trends: A Case Study in Emerging Markets. Finanse, Rynki Finansowe, Ubezpieczenia Journal, 1(79), 13-26. https://doi.org/10.18276/frfu.2016.79-01

Azmi, M. U., Andini, R., \& Raharjo, K. (2016). Analisis Pengaruh Net Profit Margin (NPM), Return On Assets (ROA) Dan Current Ratio (CR) Terhadap Harga Saham Emiten LQ45 Yang Terdaftar Di Bursa Efek Indonesia Pada Tahun 2010-2014. Journal of Accounting, 2(2), 1-10.

Gumanti, T. A. (2009). Teori Sinyal Dalam Manajemen Keuangan. Diambil dari https://www.researchgate.net/publication/265554191

Hutapea, A. W., Saerang, I. S., \& Tulung, J. E. (2017). Pengaruh Return On Assets, Net Profit Margin, Debt To Equity Ratio, Dan Total Assets Turnover Terhadap Harga Saham Industri Otomotif Dan Komponen Yang Terdaftar Di Bursa Efek Indonesia. Jurnal EMBA, 5(2), 541551.

Jusny, F. (2014). Pengaruh Konservatisme Akuntansi Terhadap Nilai Perusahaan Dimoderasi Oleh Good Corporate Governance (Studi Empiris Pada Perusahaan Sektor Retail Trade Yang Listing di Bursa Efek Indonesia. Jurnal Audit dan Akuntansi Fakultas Ekonomi Universitas Tanjungpura, 3(1), 29-52.

Muflihah, S. I. (2017). Analisis Current Ratio (CR), Return On Assets (ROA), Dan Debt To Equity Ratio (DER) Terhadap Harga Saham (Studi Kasus Pada Perusahaan Real Estate and Property yang Terdaftar di Bursa Efek Indonesia Tahun 2014-2016.

Rahmawati, S. S. (2018). Analisis Pengaruh Book Value (BV), Current Ratio (CR), Earning Per Share (EPS), Price Book Value (PBV), Price Earning Ratio (PER) Dan Total Asset Turn Over (TATO) Terhadap Harga Saham (Studi Kasus Pada Perusahaan Go Publik Yang Terdaftar Di BEI Periode 20. Universitas Islam Negeri Syarif Hidayatullah.

Rizanti, E. D., \& Husaini, A. (2017). Pengaruh Tingkat Suku Bunga, Current Ratio, Debt To Equity Ratio, Dan Return On Equity Terhadap Harga Saham (Studi Pada Perusahaan LQ45 di Bursa Efek Indonesia (BEI) Periode Februari 2013-Januari 2016. Jurnal Administrasi Bisnis, 51(1), 184-190.

Sari, H. Z., \& Hakim, A. D. M. (2017). Pengaruh Current Ratio (CR), Return On Equity (ROE), Debt to Equity Ratio (DER), Dan Earning Per Share (EPS) Terhadap Harga Saham (Pada Perusahaan Sub Sektor Property dan real estate Di Bursa Efek Indonesia (BEI) Periode 2011-2015. Jurnal Ekonomika Dan Manajemen, 6(2), 121-138.

Sekaran, U., \& Bougie, R. (2016). Research Methods For Business: A Skill-Building Approach (Edisi Ketu). Chichester, Inggris: John Wiley \& Sons, Inc. 
Sondakh, F., Tommy, P., \& Mangantar, M. (2014). Current Ratio, Debt To Equity Ratio, Return On Asset, Return On Equity Pengaruhnya Terhadap Harga Saham Pada Indeks LQ45 Di BEI Periode 2010-2014. Jurnal EMBA, 3(2), 749-756.

Syakur, A. S. (2015). Intermediate Accounting Dalam Perspektif Lebih Luas. Jakarta, Indonesia: AV Publisher.

Syari'udin, A. (2017). Pengaruh PDRB Perkapita Dan Inflasi Terhadap Penjualan Otomotif Di Indonesia. Jurnal Manajemen Dan Bisnis MEDIA EKONOMI, XVIII(1), 1-8.

Tarigan, R. (2018). Faktor-Faktor yang Mempengaruhi Harga Saham Perusahaan Makanan dan Minuman yang Terdaftar di Bursa Efek Indonesia.

Tumandung, C. O., Murni, S., \& Baramuli, D. N. (2017). Analisis Pengaruh Kinerja Keuangan Terhadap Harga Saham Pada Perusahaan Makanan Dan Minuman Yang Terdaftar Di BEI Periode 2011-2015. Jurnal EMBA, 5(2), 1728-1737.

Utami, M. R., \& Darmawan, A. (2018). Pengaruh DER, ROA, ROE, EPS Dan MVA Terhadap Harga Saham Pada Indeks Saham syariah Indonesia. Journal Of Applied Managerial Accounting, 2(2), 77-89.

Wijaya, D. (2017). Analisis Pengaruh Faktor-Faktor Fundamental Terhadap Harga Saham Pada Perusahaan Manufaktur Di Bursa Efek Indonesia (BEI). Jurnal Manajemen Bisnis Dan Kewirausahaan, 1(1), 92-102. 